\title{
受熱時に樹葉水分が温度上昇を抑制する効果の実証 ならびに樹葉の形状变化に関する実験
}

\author{
Controlling Effect of Rising Temperature by Water Content in Leaves and Form Shrinkage of Leaves \\ in the Heating Experiments
}

\author{
岩崎 哲也* \\ Tetsuya IWASAKI
}

\begin{abstract}
摘要：本研究では，樹木による防火効果に関連する $2 つ$ 事項について実験による検証を行った。1 点目として, 樹葉の温度は上昇する過程において $100^{\circ} \mathrm{C}$ 付近で一時的に横ばいの傾向を示すことが明 らかになり, $100^{\circ} \mathrm{C}$ を超えるまでの時間は落葉広葉樹が比較的短く, 常緑広葉樹は長く, タヶ・ササ 類は落葉広葉樹より長い傾向があることを確認した。また 2 点目として, 受熱時の葉の形状変化は, 樹種の違いによって著しく異なり, 広葉樹では常緑樹と落葉樹とに差は見られないこと, 針葉樹の形 状变化は小さくタケ・ササ類は大きいこと, 含水率と正の相関があり特に落葉広葉樹は含水率との正 の相関が高いことが明らかとなった。
\end{abstract}

\section{1. 研究の背景と目的}

樹種別の防火効果に関する既往研究では, 樹葉の含水率に着目したものが多く行われて (いる。これらの研究 1 (1，2，3，4），5，6)，7)では, 輻射熱に曝される際, 樹葉中に含まれる水分 が蒸散あるいは蒸発することによって, 樹葉 の温度上昇を防ぐ効果があると考えられてい る。しかし，こうした水分が示す効果を実証 的に確認した研究は無く, 樹葉の遮熱効果 ${ }^{8)}$ を裏付ける上で明らかにすべき課題であった。

また火熱に対抗して樹葉の形状が維持され なければ，樹葉の存在による遮熱効果が減少 する。樹葉の多くは熱に曝されると変形し, タケ・ササ類などに代表されるように針状に 細く丸まってしまうものがあるなど，その形 状変化は樹種によって差異が大きいと思われ る。しかし，この差異について詳しく報じた 既往研究はなく, 井上・中元による報告 ${ }^{4)}$ に おいて, 樹木の遮熱効果を検討するうえで樹 葉の形状変化に配慮することの必要性が指摘 されているのみである。このことから, 樹種 別の遮熱効果に関し, 樹種間の差が大きい, 葉の形状変化について実験により把握するこ とは, 火熱に対抗して遮熱効果を発揮する能 力を樹種別に知るための一つの評価指標にな ると考えられる。一方, 既往研究 ${ }^{9), 10)}$ では 樹冠空隙率が計測されており, この計測個体 の值を代表例として用い樹木背後の輻射受熱 量の計算に利用するなどの展開があったが, 日照や風速などの環境条件や樹勢, 樹齢, 剪 定などの管理状態等による個体差が大きいこ とが課題であった。そのため, 個体差がより 少ない，樹葉そのものの特性である形状の持
続性についても樹種別の遮熱効果を評価する ための一つの指標としてとらえ, 樹冠空隙率 など樹木の特性, 火災性状, 周辺条件など他 の評価指標とあわせて樹種別の遮熱効果を考 えるうえでの資料となるよう整理しておきた い。

本研究では, 上記 2 つの事項について実験 による検証を行うことにより, 樹葉の遮熱効 果を樹種別に比較するための一助とする。

\section{2. 樹葉中に含まれる水分による効果の実証}

\section{(1) 実験の着眼点}

火災などの受熱時, 樹葉中の水分は温度上 昇とともに空気中に失われていくと考えられ ている。この過程の検証は, 樹木に防火効果 があることを実証するために必要であり, 既 往研究 ${ }^{2,5)}$ では受熱時の葉面や葉裏面の温 度変化が計測されている。しかし, その推移 において水分がどの時点で蒸発しているのか, これまでの研究では明らかでない部分があっ た。これら既往研究での計測は目視に基づく むので, その計測間隔は短くても 10 秒以上 である。樹葉によっては 60 秒以内に $500^{\circ} \mathrm{C}$ 近くも温度が上昇するものがあることから， 葉の水分が輻射熱によって蒸発し急速に失わ れていく状況が，10 秒以上の測定間隔では 捉えられなかった可能性がある。そこで本実 験では，より短い間隔で温度の推移を計測す ることにより水分の効果について検証してい くこととしたい。

\section{(2) 実験概要}

試験装置は, 独立行政法人建築研究所 (実験当時: 建設省建築研究所) が保有する
コーンカロリーメーター（東洋精機製作所製） を用いた。この装置は, コーンヒー夕, 排気 フード，ダクト，架台，ガスサンプリング装 置, ガス分析計, 試験体ホルダーなどで構成 され, 電熱式のコーンヒータの直下に試験体 ホルダーが設置される。試験体ホルダーは試 験体の形状が変化しないよう固定が可能な構 造で, コーンヒータおよび試験体ホルダーは 開放型である。また，建築材料の燃焼速度計 測のための ISO/TC92 に準拠している。今 回の計測では燃焼速度を求めないが，樹葉な ど小型の供試体に対する操作性, コーンヒー 夕や熱流速計の安定性などから用いることに した。計測結果の比較は, この試験方法に準 拠する場合において有効とするものである。 加熱強度は $20 \mathrm{~kW} / \mathrm{m}^{2}$ に設定し, 各々の樹種 について 3 回の試験を実施した。また, 熱電 対およびデータロガー（サーモダック E ）を 用い, 2 秒間隔で葉裏温度の計測を行った。 供試体は, 表- 1 に示す 17 種である。

\section{(3) 葉裏温度の計測結果および考察}

図-1にアオキ Aucuba japonica, 図一 2 にサンゴジュViburnum awabuki, 図一 3 にアジサイ Hydrangea macrophylla，の 温度計測值のグラフを揭載する。また, こ の各々の $100^{\circ} \mathrm{C}$ 付近を拡大したものを図 -4 ～図-6に示す。図-1〜図-3それぞれ 3 回の試験の温度推移から, 樹種ごとに類似 した傾向があることが見て取れる。また図一 4 ～図- 6 から, 輻射熱に曝された樹葉裏 面の温度は, 試験開始直後から急速に上昇 していくが， $100^{\circ} \mathrm{C}$ 付近に達すると一時的に 横這いの傾向を示すことが分かる。こうし

*(財)練馬区都市整備公社 Nerima Urban Development Corporation 
た傾向は，水を加熱した場合の温度推移と同 様である。また，その後しばらく $100^{\circ} \mathrm{C}$ 付近 を維持したのち再度上昇をはじめる。この傾 向は, 17 種全種全試験で確認された。

\section{表 -1 供試樹種（葉裏温度の計測）}

\begin{tabular}{|c|c|}
\hline & 樹種（採取・計測日：全て 1990） \\
\hline 常緑広葉樹 & 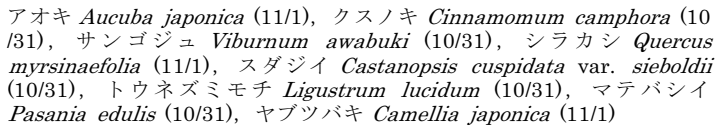 \\
\hline 落葉広葉樹 & $\begin{array}{l}\text { アカメガシワ Mellotus japonicus (10/30), アジサイ Hydrangea } \\
\text { macrophylla (10/31), イチョウ Ginkgo biloba (10/31), ウメ Prunus } \\
\text { mume (10/31), ケヤキZelkova serrata (10/30), ヤマザクラ Prunus } \\
\text { jamasakura (10/31), ヤマモミジ Acer palmatum var. matumurae } \\
(10 / 31)\end{array}$ \\
\hline タケ・ササ類 & 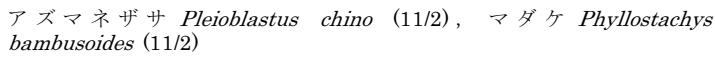 \\
\hline
\end{tabular}

採取場所：つくば市立原

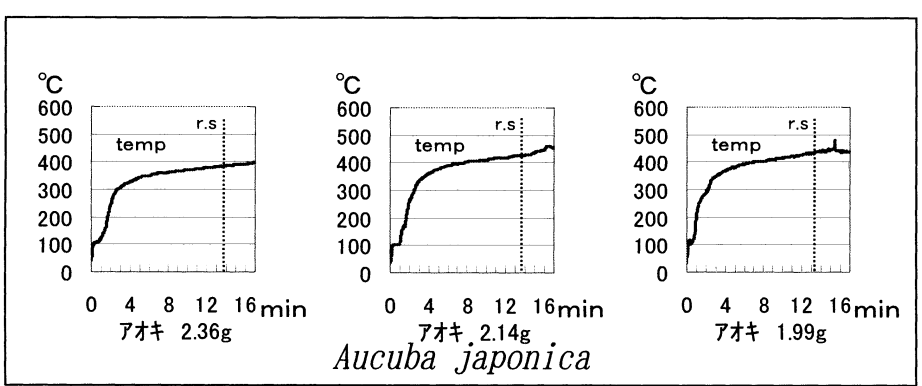

図-1 樹葉裏温度の経時変化（アオキ 輻射熱 $20 \mathrm{~kW} / \mathrm{m}^{2}$ )

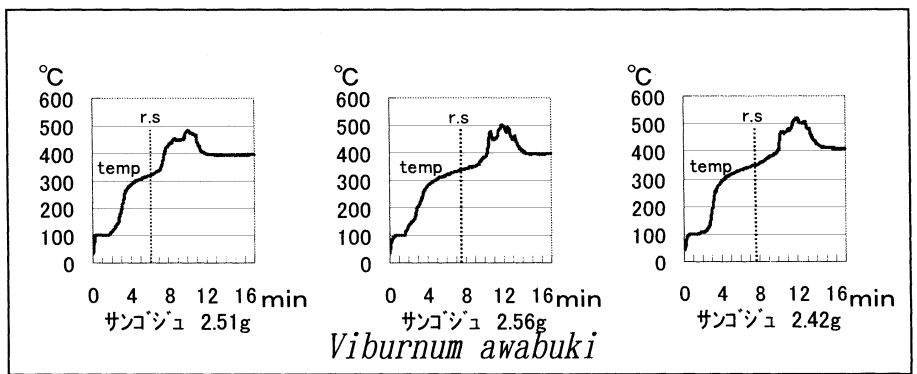

図ー2 樹葉裏温度の経時変化（サンゴジュ 輻射熱 $20 \mathrm{~kW} / \mathrm{m}^{2}$ )

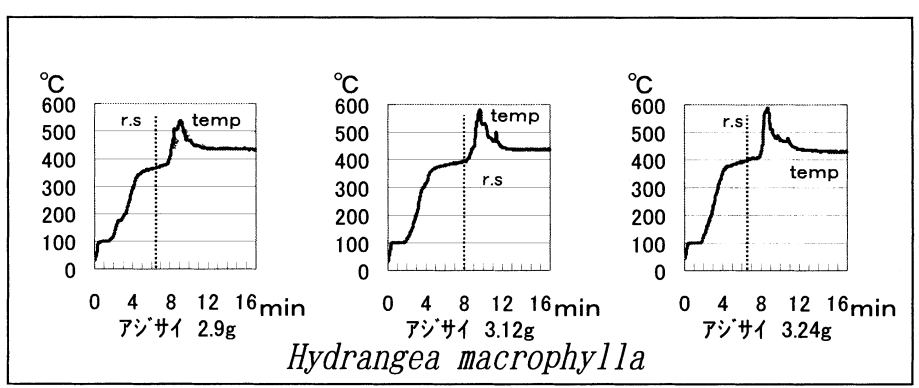

図一 3 樹葉裏温度の経時変化（アジサイ 輻射熱 $20 \mathrm{~kW} / \mathrm{m}^{2}$ )

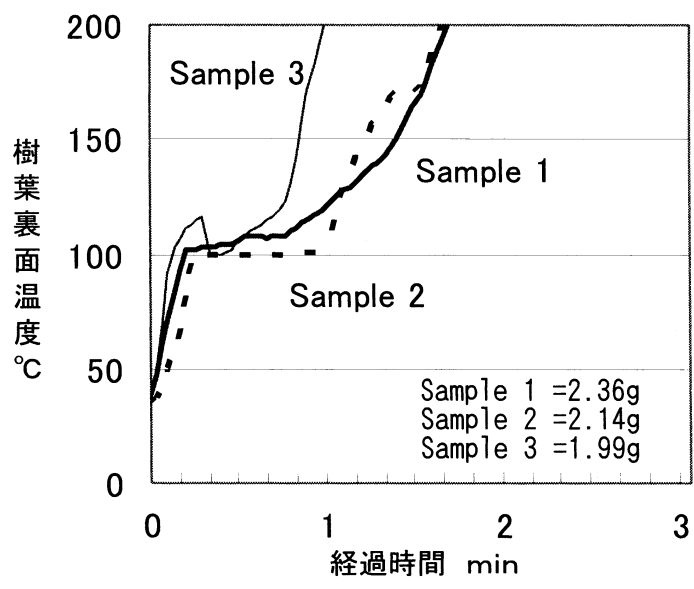

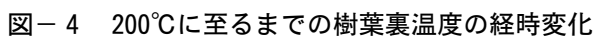
(アオキ Aucuba japonica 輻射熱 $20 \mathrm{~kW} / \mathrm{m}^{2}$ )

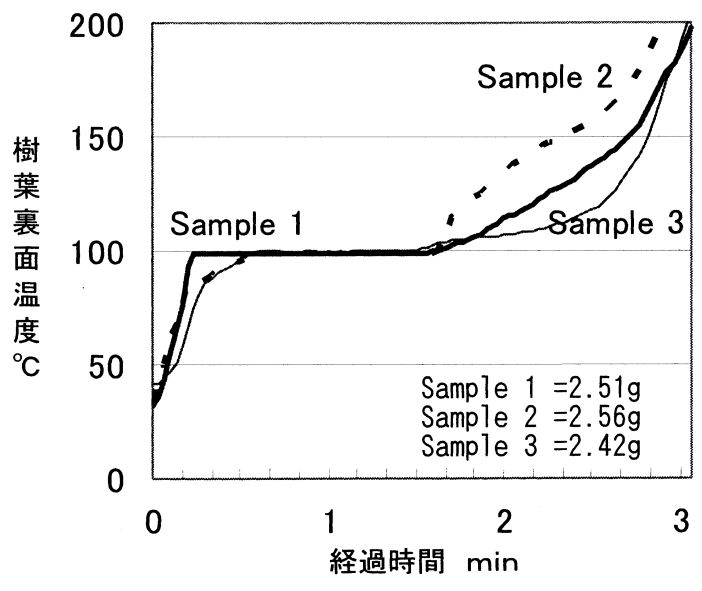

図ー $5200^{\circ} \mathrm{C}$ に至るまでの樹葉裏温度の経時変化 （サンゴジュViburnum awabuki 輻射熱 $20 \mathrm{~kW} / \mathrm{m}^{2}$ )

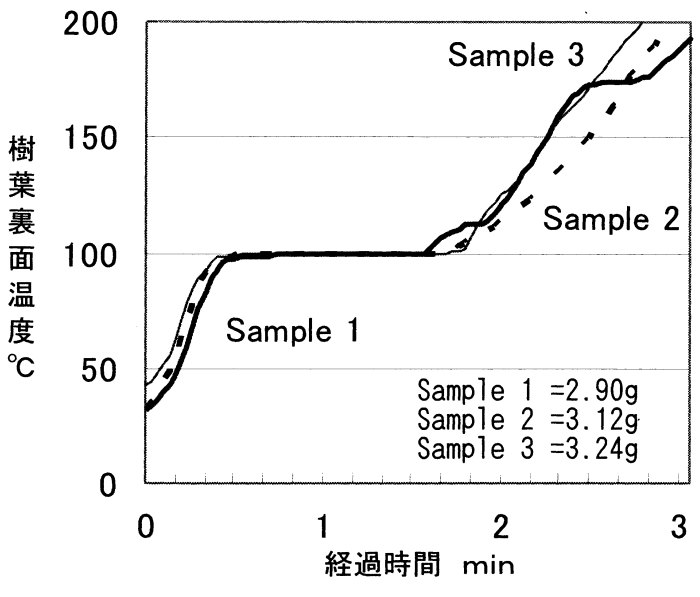

図－6 $200^{\circ} \mathrm{C}$ に至るまでの樹葉裏温度の経時変化 (アジサイ Hydrangea macrophylla 輻射熱 $20 \mathrm{~kW} / \mathrm{m}^{2}$ ) 
これらの温度推移から, $100^{\circ} \mathrm{C}$ 付近より低 い温度では輻射熱による温度上昇にともない 樹葉内部に蓄えられた水分が蒸発あるいは蒸 散している状態であり，樹葉中の水分による 効果を示していると考えられる。また，100 ${ }^{\circ} \mathrm{C}$ 以下を維持する時間が長いほど，水分を保 持することによる効果が大きいと考えられる。 表 -2 に, $100^{\circ} \mathrm{C}$ 付近の横這い状態が終わる までの時間の平均值を整理する。この時間は, 温度上昇曲線の傾きが急変する点をグラフ上 から読み取ったものである。

この表の樹種を見る限り, 落葉広葉樹は比 較的水分保持時間が短く, 常緑広葉樹は長い。 タケ・ササ類はアズマネザサ Pleioblastus chino とマダケ Phyllostachys bambusoides のみの試験のためさらに多くの樹種について 検証が必要と思われるが, 落葉広葉樹より水 分保持時間が長い。

\section{3. 受熱時の樹葉の形状変化に関する検証}

\section{(1) 実験の着眼点}

既往研究 ${ }^{5}$ では, 輻射受熱時, 樹木の最前 面の葉が遮熱効果を発揮することにより，そ の背後にある葉は長時間緑色を保つことが実 験により確認されている。したがって, 最前 面の葉が熱によって変形もしくは落葉しても, その次の葉が新たな遮熱効果を発揮し, その 葉が失われてもさらに次の葉が新たな遮熱効 果を発揮するというのである。しかし, 樹木
は樹冠の表層が最も強い太陽光を受けるため 樹冠内部は葉の密度が疎になっていることが 少なくない。また, 都市における多くの住宅 地の庭や小公園では樹木が豊かに枝葉を伸ば せるスペースは限られており, 幾重にも葉が 重なり合うことが期待できない場所が多い。 このように, 都市の屋外居住空間においては 樹冠全体よりも一枚一枚の葉が樹種別の指標 性を持つ場合がある。

一方，樹葉は水分が無くなるとともに萎れ， 変形することが経験的に知られており, 樹種 によっては遮熱効果があまり発揮できないと 思われるものもある。その様子は, スルメを 焼いた時のように同じ方向に丸く変形するこ とから, その程度は葉の形質の違いに影響さ れることが予想される。したがって, 樹種ご とに特徵を持つと仮定される。

こうしたことから, 受熱時の葉の形状変化 を測定しその特性を整理することにより，樹 種別の遮熱効果を評価するための一助とした い。

\section{（2）実験概要}

供試体とした樹種は, 表 -3 の 55 種であ り, 各樹種について 6 枚の当該年に展開した 葉を採取した。これらは, 公園や庭など屋外 居住空間において一般的に植栽されていると 思われる樹種を選定したものである。樹葉の 採取は 2001 年および 2002 年の 6 月から 9 月 に行った。採取場所は, 主として東京都港区
芝公園周辺である。

そして, 恒温乾燥炉（島津製作所製）を用 いて強熱減量を避けるため $110^{\circ} \mathrm{C} に て$ 加熱し, 水分減少が確認されなくなるまで师乾を行っ た。恒温乾燥炉の熱源は, 前述のコーンカロ リーメーターと同様に安定して熱を発生する 電熱式である。

\section{（3）形状変化率の測定}

前項の加熱実験の前および後に形状変化率 (本研究では, 樹葉の最大投影面積の縮小比 を形状変化率とする。）の測定を行った。

（4）形状变化率に関する実験結果の整理と 考察

実験の結果, 例えば, 図一 7 に示すカナメ モチ Photinia glabra のようにほとんど形 状が変化しないものがある一方, 図一 8 キョ ウチクトウ Nerium indicum のように著し く萎縮変形する樹種があり,この 2 図に示す 12 枚の樹葉の形状変化からもその割合は樹 種によって特性づけられているように見受け られる。そこで, 55 種それぞれの試験の標 準偏差（ $\mathrm{n}=6 ）$ を計算すると，表 -4 にある ように全体の約 $85 \%$ である 47 種について変 動係数が $30 \%$ 以内と比較的小さい。

特に, イチョウ Ginkgo biloba，八ナズ オウ Cercis chinensis, マダケ, フョウ Hibiscus mutabilis, ヤマモミジ Acer palmatum var. matumuraeなどは值のば らつきと変動係数がともに小さく, 形状変化
表－2 樹葉の水分保持時間（輻射熱 $20 \mathrm{~kW} / \mathrm{m}^{2}$ )

\begin{tabular}{|c|c|c|}
\hline 樹 種 & $\begin{array}{l}\text { 水分保持 } \\
\text { 時間(秒)\% }\end{array}$ & 標準偏差 \\
\hline ヤマモミジ Acer palmatum var. matumurae & 20.7 & 4.6 \\
\hline ケヤキ Zelkova serrata & 24.0 & 6.9 \\
\hline アカメガシワ Mellotus japonicus & 41.3 & 11.0 \\
\hline ヤマザクラＰrunus jamasakura & 44.7 & 34.5 \\
\hline マテバシイ Pasania edulis & 52.7 & 5.8 \\
\hline アズマネザサＰleioblastus chino & 52.7 & 21.4 \\
\hline シラカシ Quercus myrsinaefolia & 54.0 & - \\
\hline アオキ Aucuba japonica & 56.0 & 5.7 \\
\hline クスノキ Cinnamomum camphora & 62.0 & 8.0 \\
\hline ウメ Prunus mume & 80.0 & 20.8 \\
\hline スダジイ Castanopsis cuspidata var. sieboldii & 81.3 & 22.0 \\
\hline イチョウ Ginkgo biloba & 84.7 & 17.5 \\
\hline トウネズミモチＬigustrum Iucidum & 94.0 & 17.1 \\
\hline ヤブツバキ Camellia japonica spp. & 101.3 & 8.1 \\
\hline アジサイ Hydrangea macrophylla & 106.7 & 5.8 \\
\hline サンゴジュ Viburnum awabuki & 121.3 & 31.9 \\
\hline マダケ Phyllostachys bambusoides & 130.0 & 14.0 \\
\hline $\begin{array}{lc}\text { 平均 } & 71.0 \\
\text { 常緑樹平均 } & 77.8 \\
\text { 落葉樹平均 } & 57.4 \\
\text { タケ・ササ類平均 } & 91.3\end{array}$ & & \\
\hline
\end{tabular}

\section{表 -3 供試樹種（葉の形状変化率）}

\begin{tabular}{|c|c|}
\hline & 樹＼cjkstart種 \\
\hline $\begin{array}{c}\text { 常緑 } \\
\text { 広葉樹 } \\
\text { (26 種) }\end{array}$ & $\begin{array}{l}\text { アオキ Aucuba japonica, アラカシ Quercus glauca, ウバメガシ Quercus } \\
\text { phillyraeoides, オオムラサキツツジRhododendron pulchrum var. speciosum, } \\
\text { カクレミノ Dendropanax trifidus, カナメモチPhotinia glabra, カロライナ } \\
\text { ジャスミン Gelsemium sempervirens, キョウチクトウNerium indicum, キンモ } \\
\text { クセイ Osmanthus fragrans var. aurantiacus, クスノキCinnamomum camphora, } \\
\text { クチナシ Gardenia jasminoides f. grandiflora, サザンカCamellia sasanqua, } \\
\text { サンゴジュViburnum awabuki, シャリンバイ Rhaphiolepis umbellata, スダジ } \\
\text { イ Castanopsis cuspidata var. sieboldii, チャノキThea sinensis, トウネ } \\
\text { ズミモチ Ligustrum lucidum, トベラ Pittosporum tobira, ヒイラギナンテン } \\
\text { Mahonia japonicus, ビワ Eriobotrya japonica, ヘデラ・ヘリックス Hedera } \\
\text { helix, マサキEuonymus japonicus, マテバシイ Pasania edulis, マメツゲ } \\
\text { Ilex crenata f. bullata, ヤブツバキCamellia japonica, ヤマモモMyrica } \\
\text { rubra }\end{array}$ \\
\hline $\begin{array}{c}\text { 落葉 } \\
\text { 広葉樹 } \\
\text { (23 種) }\end{array}$ & $\begin{array}{l}\text { アキニレ Ulmus parvifolia, アジサイ Hydrangea macrophylla, アメリカヤマ } \\
\text { ボウシ Cornus florida, イチョウ Ginkgo biloba, ウメ Prunus mume, エドヒ } \\
\text { ガンPrunus pendula f. ascendens, エノキCeltis sinensis var. japonica, } \\
\text { ケヤキZelkova serrata, シナレンギョウForsythia viridissima, セイヨウハ } \\
\text { コヤナギ Populus nigra var. italica, ソメイヨシノ Prunus yedoensis, ツタ } \\
\text { Parthenocissus tricuspidata, トウカエデAcer buergerianum, バージニアッ゙ } \\
\text { タ Parthenocissus quinquefolia, ハコネウツギ Weigela coraeensis, ハナズ } \\
\text { オウ Cercis chinensis, ハリエンジュ Robinia pseudo-acacia, フヨウ } \\
\text { Hibiscus mutabilis, ムクノキAphananthe aspera, ムラサキシキブ } \\
\text { Callicarpa japonica, ヤマグワ Morus bombycis, ヤマブキKerria japonica, } \\
\text { ヤマモミジAcer palmatum var. matumurae }\end{array}$ \\
\hline $\begin{array}{c}\text { 針葉樹 } \\
(3 \text { 種 })\end{array}$ & $\begin{array}{l}\text { カイヅカイブキ Juniperus chinensis cv. Kaizuka, サワラ Chamaecyparis } \\
\text { pisifera, シノブヒバ Chamaecyparis pisifera 'Plumosa' }\end{array}$ \\
\hline $\begin{array}{l}\text { タケ・ } \\
\text { ササ類 } \\
(3 \text { 種 })\end{array}$ & $\begin{array}{l}\text { アズマネザサ Pleioblastus chino, オカメザサ Shibataea kumasaca, マダケ } \\
\text { Phyllostachys bambusoides }\end{array}$ \\
\hline
\end{tabular}


率は樹種によって特性づけられていると考え られる。

また，図ー 9 に主な樹種の 2 階調化画像を 例示する。この図にあるように，樹種によっ て変化が大きいものと小さいものがある。さ らに, 生活・形態別の形状変化率の平均值を 表 -5 に示す。今回実験を行った 55 種に限 定する限り, 常緑広葉樹（26 種）乙落葉広 葉樹（23 種）の平均値には差がなく, 常緑 針葉樹 (3 種) の形状変化率は低く, 夕ケ・ ササ類（3 種）は高い。

また，図-10に生活・形態別に整理した 形状変化率のグラフを示す。このグラフにあ
るように, 形状変化率の低い樹種は, 常緑広 葉樹ではカナメモチ，キンモクセイ Osmanthus fragrans var. aurantiacus, マテバシイ Pasania edulis, ヘデラ・ヘリッ クス Hedera helix, マサキ Euonymus japonicus など, 落葉広葉樹はアキニレ Ulmus parvifolia, トウカエデAcer buergerianum, ムクノキ Aphananthe aspera, 八ナズオウなどであり, 常緑針葉 樹はいずれも形状変化率が低い。一方，夕ケ・ ササ類, アラカシ Quercus glauca, キョウ チクトウ, カクレミノ, Dendropanax trifidus, ヤマモミジ, ケヤキ, ヤマグワ
Morus bombycis, ハリエンジュ Robinia pseudo-acacia などは形状変化率が高く, と りわけタケ・ササ類は原形の 3 割以下にまで 萎縮することが分かる。

これらは, 比較的葉の厚い樹種は形状変化 率が低く, 葉の薄い樹種は形状変化率が高い 傾向があるように見受けられるが，へデラ・ ヘリックスが低くキョウチクトウが高いなど, 一概には言えない。そして, 夕ケ・ササ類や キョウチクトウのように, 多数の側脈が平行 する樹種や，ヤマモミジやヤマグワのように 葉の切れ込みが深い樹種は比較的形状変化率 が高い。

\section{表 -4 形状变化率に関する標準偏差および変動係数}

（樹葉 6 枚当たり）

\begin{tabular}{|c|c|c|c|c|c|c|c|}
\hline \multirow[b]{2}{*}{ 樹 種 } & \multicolumn{3}{|c|}{ 形状変化率 } & \multirow[b]{2}{*}{ 樹 種 } & \multicolumn{3}{|c|}{ 形状変化率 } \\
\hline & $\begin{array}{l}\text { 平均 } \\
(\%)\end{array}$ & $\begin{array}{l}\text { 標隻 } \\
\text { 偏差 }\end{array}$ & $\begin{array}{l}\text { 変動 } \\
\text { 倸数 } \\
\end{array}$ & & $\begin{array}{l}\begin{array}{l}\text { 平均 } \\
(\%)\end{array} \\
\end{array}$ & \begin{tabular}{|l|} 
標鹤 \\
偏差 \\
\end{tabular} & \begin{tabular}{|l} 
変動 \\
倸数
\end{tabular} \\
\hline イチョウ Ginkgo biloba & 46.1 & 1.1 & 0.02 & アラカシ Quercus glauca & 61.8 & 6.3 & 0.10 \\
\hline ハナズオウ Cercis chinensis & 22.0 & 1.9 & 0.09 & ヤマモモ Myrica rubra & 54.6 & 6.4 & 0.12 \\
\hline $\begin{array}{l}\text { マダケ } \\
\text { Phyllostachys bambusoides }\end{array}$ & 77.3 & 2.4 & 0.03 & |ヤマブキ Kerria japonica & 39.2 & 6.5 & 0.17 \\
\hline $\begin{array}{l}\text { フョウ } \\
\text { Hibiscus mutabilis }\end{array}$ & 53.6 & 2.8 & 0.05 & \begin{tabular}{|l|}
$\mid$ バージニアヅタ \\
Parthenocissus quinquefolia
\end{tabular} & 49.2 & 6.7 & 0.14 \\
\hline $\begin{array}{l}\text { ヤマモミジ Acer palmatum } \\
\text { var. matumurae }\end{array}$ & 66.7 & 3.1 & 0.05 & \begin{tabular}{|l} 
カナメモチ \\
Photinia glabra
\end{tabular} & 12.1 & 6.9 & 0.57 \\
\hline $\begin{array}{l}\text { キンモクセイ Osmanthus } \\
\text { fragrans var. aurantiacus }\end{array}$ & 16.7 & 3.2 & 0.19 & |サザンカ Camellia sasanqua & 43.3 & 6.9 & 0.16 \\
\hline $\begin{array}{l}\text { マサキ } \\
\text { Euonymus japonicus }\end{array}$ & 21.2 & 3.2 & 0.15 & \begin{tabular}{|l} 
オカメザサ Shiba \\
kumasaca
\end{tabular} & 72.2 & 7.2 & 0.10 \\
\hline $\begin{array}{l}\text { ツタ Parthenocissus } \\
\text { tricuspidata }\end{array}$ & 31.6 & 3.2 & 0.10 & \begin{tabular}{|l|l} 
Rundusacd \\
Pベラ \\
Pittosporum tobira
\end{tabular} & 56.4 & 7.6 & 0.13 \\
\hline $\begin{array}{l}\text { マメツダ } \\
\text { Ilex crenata f. bullata }\end{array}$ & 28.8 & 3.6 & 0.12 & \begin{tabular}{|l} 
カクレミノ \\
Dendropanax trifidus
\end{tabular} & 60.6 & 7.7 & 0.13 \\
\hline $\begin{array}{l}\text { アズマネザサ } \\
\text { Pleioblastus chino }\end{array}$ & 75.1 & 3.7 & 0.05 & ウメ Prunus mume & 51.2 & 7.8 & 0.15 \\
\hline $\begin{array}{l}\text { シノブヒバ Chamaecyparis } \\
\text { pisifera 'Plumosa' }\end{array}$ & 23.5 & 3.7 & 0.16 & ヤマグワ Morus bombycis & 58.2 & 7.9 & 0.14 \\
\hline $\begin{array}{l}\text { アジサイ } \\
\text { Hydrangea macrophylla }\end{array}$ & 40.2 & 3.8 & 0.09 & \begin{tabular}{|l} 
スダジイ Castanopsis \\
cuspidata var. sieboldii
\end{tabular} & 42.4 & 8.0 & 0.19 \\
\hline $\begin{array}{l}\text { アメリカヤマボウシ } \\
\text { Cornus florida }\end{array}$ & 35.2 & 4. 2 & 0.12 & \begin{tabular}{|l} 
ウハバガシ \\
Quercus phillyraeoides
\end{tabular} & 34.0 & 8.1 & 0.24 \\
\hline $\begin{array}{l}\text { ベラ・ヘリックス } \\
\text { Hedera helix }\end{array}$ & 20.2 & 4.3 & 0.21 & $\begin{array}{l}\text { ヘコネウツギ } \\
\text { Weigela coraeensis }\end{array}$ & 45.6 & 8.5 & 0.19 \\
\hline $\begin{array}{l}\text { カイヅカイブキ Juniperus } \\
\text { chinensis cv. Kaizuka }\end{array}$ & 20.5 & 4. 5 & 0.22 & \begin{tabular}{|l} 
クチナシ Gardenia \\
jasminoides f. grandiflora
\end{tabular} & 30.4 & 8.8 & 0.29 \\
\hline $\begin{array}{l}\text { ソメイヨシ) } \\
\text { Prunus yedoensis }\end{array}$ & 34.0 & 4. 5 & 0.13 & \begin{tabular}{|l} 
エドヒガン \\
Prunus pendula f. ascendens
\end{tabular} & 30.5 & 8.9 & 0.29 \\
\hline $\begin{array}{l}\text { ヒイラギナンテン } \\
\text { Mahonia japonicus }\end{array}$ & 48.0 & 4.6 & 0.10 & ビワ Eriobotrya japonica & 34.5 & 9.3 & 0.27 \\
\hline ケヤキ Zelkova serrata & 59.0 & 4.7 & 0.08 & $\begin{array}{l}\text { ヤブツバキ } \\
\text { Camellia japonica }\end{array}$ & 30.4 & 0.1 & 0.33 \\
\hline $\begin{array}{l}\text { ムラサキシキブ } \\
\text { Callicarpa japonica }\end{array}$ & 51.9 & 4.7 & 0.09 & $\begin{array}{l}\text { アキニレ } \\
\text { Ulmus parvifolia }\end{array}$ & 16.3 & 0.8 & 0.66 \\
\hline $\begin{array}{l}\text { Pテバシイ } \\
\text { Pasania edulis }\end{array}$ & 19.9 & 4.7 & 0.24 & $\begin{array}{l}\text { シャリンバイ } \\
\text { Rhaphiolepis umbellata }\end{array}$ & 38.5 & 0.8 & 0.28 \\
\hline $\begin{array}{l}\text { セイヨウハコヤナギ } \\
\text { Populus nigra var. italica }\end{array}$ & 28.8 & 4.9 & 0.17 & \begin{tabular}{|l|l|} 
ムクノキ \\
Aphananthe aspera
\end{tabular} & 21.5 & 10.9 & 0.51 \\
\hline $\begin{array}{l}\text { サワラ } \\
\text { Chamaecyparis pisifera }\end{array}$ & 26.0 & 5.3 & 0.20 & \begin{tabular}{|l|l|}
$\mid$ クスノキ \\
Cinnamomum c
\end{tabular} & 53.1 & 11.6 & 0.22 \\
\hline $\begin{array}{l}\text { ハリエンジュ } \\
\text { Robinia pseudo-acacia }\end{array}$ & 58.0 & 5.4 & 0.09 & $\begin{array}{l}\text { カロライナジャスミン } \\
\text { Gelsemium sempervirens }\end{array}$ & 50.2 & 12.1 & 0.24 \\
\hline $\begin{array}{l}\text { サンゴジュViburnum } \\
\text { awabuki }\end{array}$ & 57.4 & 5.6 & 0.10 & \begin{tabular}{|l|} 
シナレンギョウ \\
Forsythia viridissima
\end{tabular} & 33.3 & 12.4 & 0.37 \\
\hline アオキ Aucuba japonica & 50.6 & 5.9 & 0.12 & チャノキ Thea sinensis & 29.3 & 12.7 & 0.43 \\
\hline $\begin{array}{l}\text { トウネズミモチ } \\
\text { Ligustrum lucidum }\end{array}$ & 33.9 & 6.0 & 0.18 & \begin{tabular}{|l} 
エノキ Celtis sinensis \\
var. japonica
\end{tabular} & 30.3 & 13.0 & 0.43 \\
\hline $\begin{array}{l}\text { トウカエデ } \\
\text { Acer buergerianum }\end{array}$ & 17.9 & 6.0 & 0.34 & $\begin{array}{l}\text { キョウチクトウ } \\
\text { Nerium indicum }\end{array}$ & 62.7 & 16.8 & 0.27 \\
\hline $\begin{array}{l}\text { オオムラサキッツジ Rhododen } \\
\text { dron pulchrum var. speciosum }\end{array}$ & 35.1 & 6.1 & 0.17 & & & & \\
\hline
\end{tabular}

\section{表 -5 生活・形態別の形状変化率}

\begin{tabular}{|c|c|c|c|}
\hline \multirow{2}{*}{ 生活・形態別 } & \multicolumn{3}{|c|}{ 形状変化率䅈 } \\
\hline & 平均 $(\%)$ & 標準偏差 & 值の範囲 (\%) \\
\hline 常緑広葉樹 (26 種) & 39.5 & 15.1 & $12.1 \sim 62.7$ \\
\hline 落葉広葉樹（23 種） & 39.5 & 13.9 & $16.3 \sim 66.7$ \\
\hline 常緑針葉樹（3 種） & 23.3 & 2.8 & $20.5 \sim 26.0$ \\
\hline タケ・ササ類（3 種） & 74.9 & 2.6 & $72.2 \sim 77.3$ \\
\hline
\end{tabular}

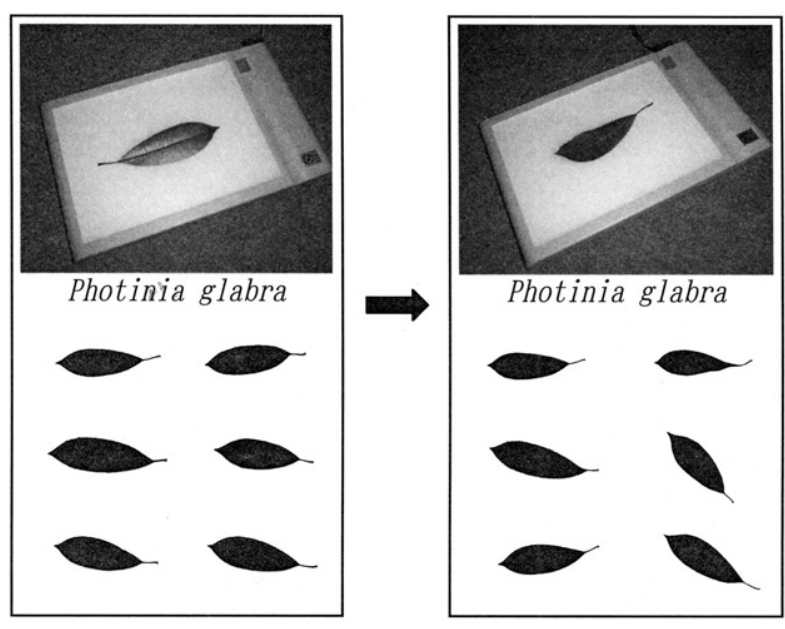

図－７寺メモチ の葉の加熱前（左）と加熱後（右）
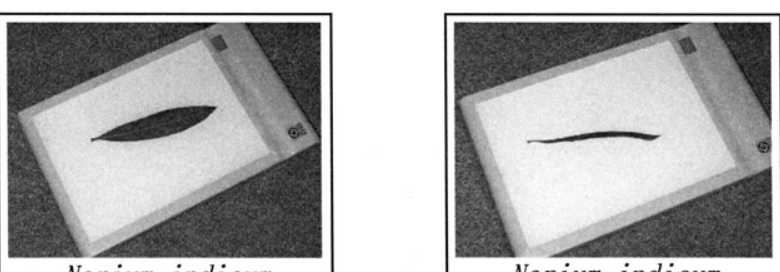

Nerium indicum
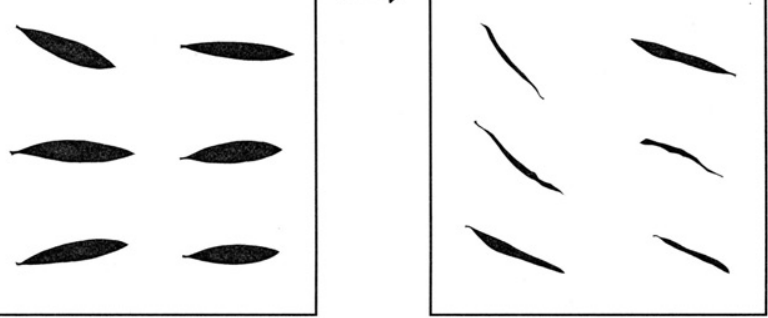

図－8 キョウチクトウの葉の加熱前（左）と加熱後（右） 


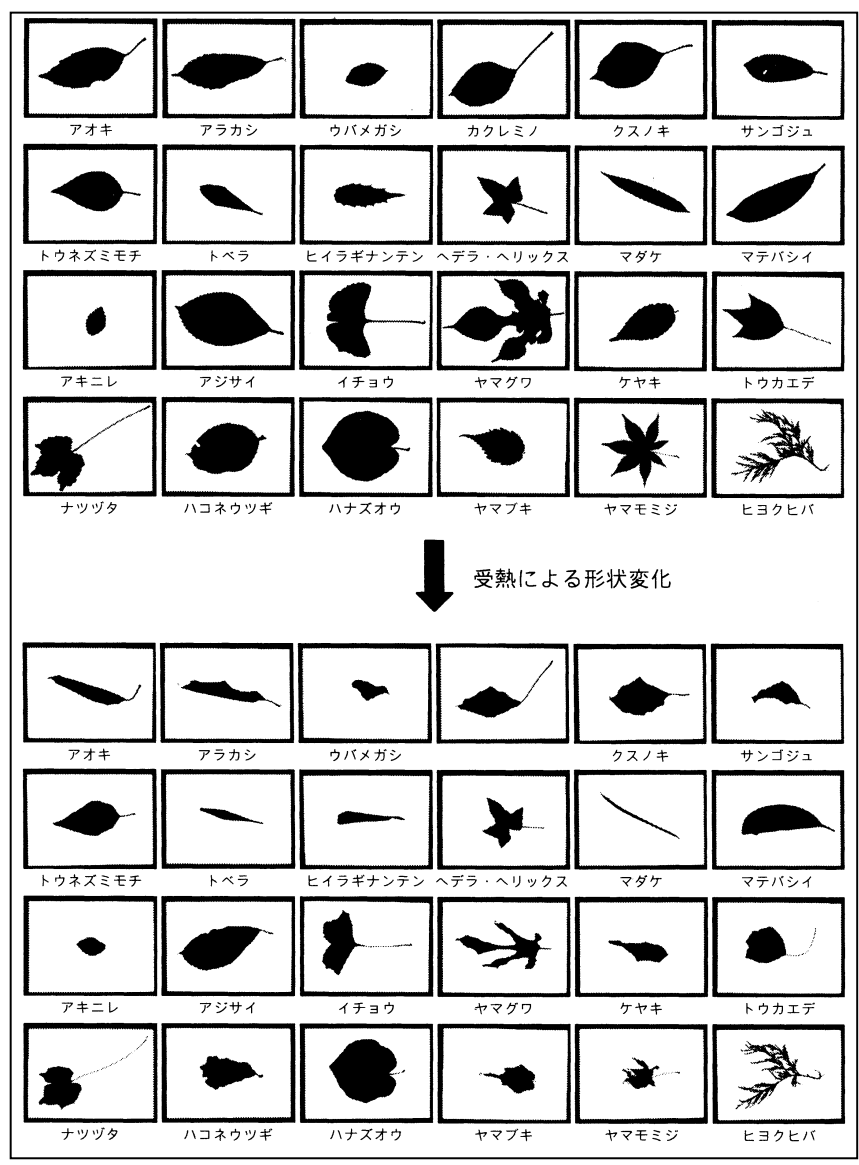

図-9 主な樹種の 2 階調化画像例
また含水率 ${ }^{11}$ との相関係数はそれぞれ下記 の通りで，広葉樹については含水率と正の相 関がある。落葉樹は比較的含水率が高い ${ }^{11)} こ$ とから，これら含水率が高い樹種は大きな形 状変化を示す傾向があると考えられる。

含水率との相関

- 常緑広葉樹 $\quad r=0.45(\mathrm{p}<0.05)$

・落葉広葉樹 $\quad r=0.65(p<0.05)$

\section{4. まとめ}

本研究では, これまで不明だった，樹葉中 の水分が受熱時の温度上昇を防ぐ効果を確認 した。それにともない下記の点が明らかになっ た。

- 落葉広葉樹は, 常緑広葉樹と比較すると 水分保持時間が短い。

- 夕ケ・ササ類は, 落葉広葉樹より水分保 持時間が長い。

また樹葉の形状変化率の計測実験により,

つぎの点が明らかになった。

- 葉の形状変化率は, 樹種によって著しく 異なる。

・ 49 種の測定に限り, 広葉樹では, 常緑
樹（26 種）と落葉

樹（23 種）とに差

は見られない。

- 6 種の測定に限

り, 針葉樹 (3

種）の形状変化

率は低く, 夕ケ・

ササ類（3 種）

は高い。

- 形状変化率は含 水率と正の相関 があり, 特に落 葉広葉樹は含水 率との正の相関 が高い。

これらの点から， 樹葉一枚ごとの遮熱 効果の持続性は樹種 によって著しく異な ると考えられる。ま た, 生活・形態別に は常緑広葉樹の水分 保持時間が長く, 遮 熱効果を持続する能 力が高いと思われる。 一方, 形状変化率か らは, 常緑針葉樹の 葉は今回測定した 3 種類に限り形状がほ

ては，追求できなかった。今後の詳しい検討 が必要であろう。また樹葉の形状変化率につ いて測定したのは 55 種であり, 生活・形態 別の傾向はこの 55 種に限定した結果にすぎ ず，都市空間に使われる樹種のみを考えても 不足がある。今後のデータの蓄積が求められ る。

謝辞

樹葉水分の効果に関する実験にあたり, 吉 田正志氏（独立行政法人 建築研究所）には 試験に関する指導を戴いた。また，岩河信文 氏, 興水肇氏（明治大学）には, 多年にわた り懇切なる指導鞭撻を睗った。また，倉本宣 氏 (明治大学), 斉藤庸平氏 (兵庫県立大学) には，専門の立場から適切なる詳しい助言を 賜った。この場を借りて, 謹んで感謝申し上 げる。

\section{補注および引用文献}

1 ) 木村英夫（1947）：防火と樹木:新都市 $1(8), 7-9$

2 ) 中村貞一 (1948) : 樹林防火力の研究第 1 報 緑地用樹木の葉の含水率と脱水 時間についての比較実験:造園雑誌 12(1), 13-17

3 ) 木村英夫 ・加藤和男 (1949) ：樹木の防 火性に関する研究: 造園雑誌 11(1), 11-15

4）井上桂 -中元六雄（1951）：樹葉の燃焼 : 日本林学会誌 33(4)，125-131

とんど変化せず，遮熱効果を持続する能力が 高いと考えられる。また, 常緑広葉樹 26 種 の中ではカナメモチ, キンモクセイ, ヘデラ・ ヘリックス, マサキなど, 落葉広葉樹 23 種 ではアキニレ, トウカエデ，ムクノキ, 八ナ ズオウなどがそれぞれ遮熱効果の持続性が高 いと考えられる。しかし今回の樹種の実験結 果を見る限り，落葉広葉樹をはじめとする広 葉樹は, 含水率が高いほど形状変化率が高い 傾向がみられること, 落葉広葉樹は常緑広葉 樹之比較すると水分保持時間が短いことから， 含水率が高いことと葉一枚の遮熱効果の持続 性とは一致しない部分がある。また，常緑針 葉樹は既存の研究において防火力が劣ると言 われる場合も多いが，輻射受熱限界位置より も離れた位置に用いるなど, 配植計画上の配 慮により遮熱力を発揮する能力を有すものと 思われる。

\section{5. 今後の課題}

今回の実験では, 形状変化率を計測するた めの樹葉の採取は 6 月から 9 月に実施したが, この間の季節や気象の変化にともなう樹種ご との葉の組織の発達や老化などの生理変化が 実験結果へどのように影響しているかについ
5 ) 岩河信文 (1982)：都市における樹木の 防火機能に関する研究 : 東京大学博士論 文

6 ) 山下邦博（1987）：林内可燃物の火災危 険について：日本火災学会論文集 37(1), 21-32

7 ) 中村彰宏（1999）：樹木の葉の水分特性 之耐火性および震災後の樹木の生育評価: ランドスケープ研究 62(3)，218-221

8 ）樹木の遮熱効果は, 枝葉や幹などの難透 熱性にもとづくものであり，本研究では 樹葉裏面の温度計測を行ったことから， 水分による効果を遮熱効果の一つとして 位置づけた。

9 ) 斉藤庸平・岩河信文（1983）：樹木の防 火機能に関する研究：造園雑誌 46(5), 158-163

10）（財）都市緑化技術開発機構・公園緑地 防災技術共同研究会編（2000）：防災公 園技術ハンドブック，290-310，公害対 策技術同友会, 東京, $329 \mathrm{pp}$

11）岩崎哲也（2005）：防火的視点からみた 各種樹葉の含水率に関する研究 : ランド スケープ研究 68(5), 525-528 


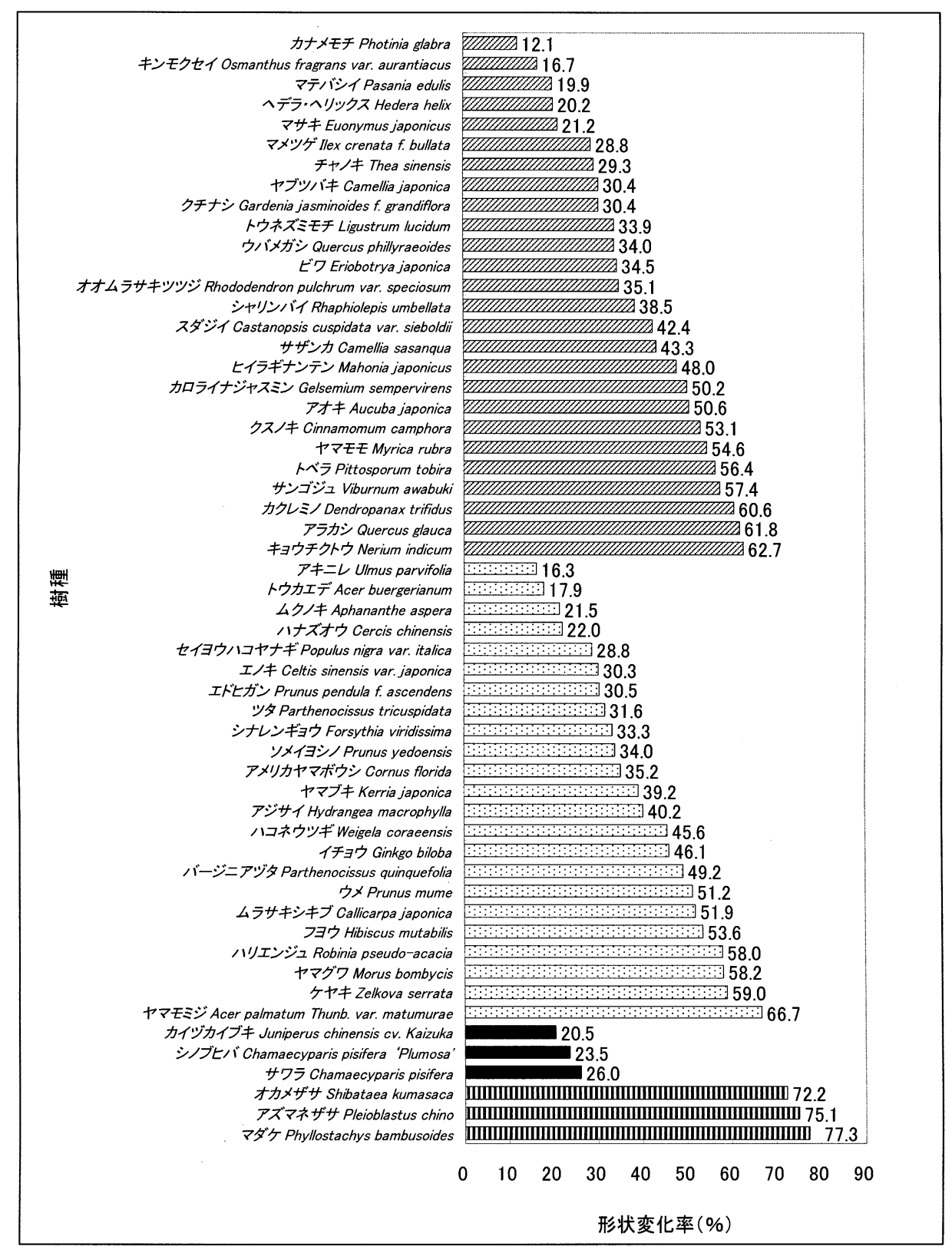

図-10＼cjkstart受熱による樹葉の形状変化率

Summary : Controlling the effect of rising temperature in the water contained in leaves was performed by continuously measuring leaf temperature on the reverse side of the leaf at intervals of two seconds during the heating experiments. Time period to maintain nearly 100 degrees $\mathrm{C}$ or less at the reverse side of leaves for 17 species of trees was also shown as the water retention time. It was observed that trees such as Phyllostachys bambusoides, Viburnum awabuki, Hydrangea macrophylla, Camellia japonica spp., etc. had long water retention time, and Acer palmatum var. matumurae, Zelkova serrata, Mellotus japonicus, Prunus jamasakura, etc. had short water retention time.

Moreover, the form shrinkage of leaves by heat was measured in relation to the heat interception effect of a leaf. As a result of the heating experiments for 55 species of trees, it was found that the rate of shrinkage of leaves varies from one species of trees to another. It was also found that there is a high positive correlation between the ratio of water content and rate of shrinkage. As a result, it was established that, within the limits of this experiments, evergreen needle-leaf trees demonstrated the smallest shrinkage rate. Evergreen broad-leaved trees such as Photinia glabra, Osmanthus fragrans var. aurantiacus, Pasania edulis, Hedera helix and Euonymus japonicus and deciduous broad-leaved trees such as Ulmus parvifolia, Acer buergerianum, Aphananthe aspera and Cercis chinensis also show smaller shrinkage rate. It is clear that the higher the ratio of form shrinkage, the higher the ratio of water content in the broadleaf trees, especially in deciduous broad-leaved trees. In addition, an opposite relationship can be seen between high water content ratio and the high durability of heat interception in a leaf.

(2005.8.19受付，2006.11.6 受理） 